\title{
The Recognition of Capital Structure Peer Effect of Chinese Listed Companies
}

\author{
Yongjia Liang \\ Jinan University, Guangzhou, China \\ Email: 371491248@qq.com
}

Received 4 June 2016; accepted 12 June 2016; published 15 June 2016

Copyright (C) 2016 by author and Scientific Research Publishing Inc.

This work is licensed under the Creative Commons Attribution International License (CC BY). http://creativecommons.org/licenses/by/4.0/

(c) $\underset{\mathrm{EY}}{\mathrm{EP}}$ Open Access

\section{Abstract}

The capital structure of listed companies is significantly affected by that of peer companies in the same industry. This phenomenon is called the peer effect of capital structure. This paper studies the peer effect of capital structures of listed companies in the same industry in the Chinese A-share market. Unlike previous literatures simply using the average industry capital structure as the explanatory variable, by constructing the instrumental variable (equity shock), this paper successfully and accurately identifies the peer effect. Through the empirical analysis, this paper has found the following conclusions: 1 . The peer effect's ability to explain the capital structure of the company itself is more important than the common capital structure influence factors in the previous literatures; 2 . Peer firms play an important role for the company's own capital structure. Specifically, the company's own capital structure will respond to the capital structures of peer firms, rather than other financial characteristics of peer firms. The conclusion of this paper has certain enlightenment significance on the capital structure theory and capital decision-making behaviors of Chinese listed companies. The capital structure of listed companies in China is not independently decided by the company managers, but in the process of decision-making the capital structures of peer firms is considered as the important reference factor. This will provide a new angle for the research on capital structure. The strong correlation among capital decisionmaking of peer firms will be considered.

\section{Keywords}

Peer Effect, Capital Structure, Equity Shock

\section{Introduction}

The capital structure theory is the most intensively investigated field with the most research results in the 
corporate finance theory, and one of the most important problems. The old enterprise capital structure theory mainly includes MM theorem, MM model considering the enterprise income tax, tax difference school, bankruptcy cost school and balance theory, etc.; while the new capital structure theory mainly includes four schools, which are agency cost theory, signaling theory, control right theory and industrial organization theory of capital structure.

The peer effect can be interpreted as the mutual learning of different individuals in the same group. Restricted by their own information environment, the company managers cannot determine the optimal capital structure for their companies. As a result, when determining the company's own capital structure, managers focus on capital structures or other financial characteristics of peer firms. In fact, the behavior of peer firms action is a important explanatory variable for the capital decision-making of a lot of companies. Evidence shows that the company's own capital structure is affected by that of peer firms. Through the questionnaire survey of CFOs of listed companies, Graham \& Harvey (2001) [1] proposed that a number of CFOs thought that when they made capital decision for their own companies, behaviors of peer firms played an important role of reference. In addition, in their literatures, Welch (2004) [2], Mackay \& Phillips (2005) [3] and Frank \& Goyal (2009) [4] pointed out that in the average industry capital structure was an important and significant explanatory variable affecting the capital structure of the company itself.

The purpose of this paper is to discuss about whether behaviors of peer firms affect the capital structure of the company itself. In this paper, the structure of the remaining parts is as follows. Chapter 2 is the recognition model of peer effect. The traditional model, the construction of equity shock and recognition strategy are introduced. Chapter 3 is the empirical analysis. Chapter 4 is conclusion and enlightenment.

\section{The Recognition Model of Peer Effect}

Referring to previous empirical literature on the capital structure (Rajan \& Zingales, 1995 [5]; Frank \& Goyal, 2009), the empirical model adopted in this paper is as follows:

$$
y_{i j t}=\alpha+\beta \bar{y}_{-i j t}+\gamma^{\prime} \bar{X}_{-i j t-1}+\lambda^{\prime} X_{i j t-1}+\delta^{\prime} \mu_{j}+\phi^{\prime} v_{t}+\varepsilon_{i j t}
$$

The subscript $i, j$ and $t$ in the model corresponds to the $i^{\text {th }}$ listed company, the $j^{\text {th }}$ industry and the $t^{\text {th }}$ year, respectively. The dependent variable $y_{i j t}$ measures the capital structure of the listed company. K-dimension vector $\bar{X}_{-i j t-1}$ and $X_{i j t-1}$ represent average of peers and the company's own financial characteristics, respectively. $\mu_{j}$ and $v_{t}$ represent the deviation of fixed effect of industry and year, respectively. Finally, $\varepsilon_{i j t}$ is the disturbing term of the $\mathrm{i}^{\text {th }}$ company in the $\mathrm{n}^{\text {th }}$ year. $\left(\alpha, \beta, \gamma^{\prime}, \lambda^{\prime}, \delta^{\prime}, \phi^{\prime}\right)$ is the parametric variable in the model.

\section{The Construction of Equity Shock}

Another method for recognization of peer effect used in this paper is construction of instrumental variable. Stock return is a known determinant of capital structure (Marsh, 1982 [6]). And then, we constructed the traditional asset pricing model. In order to remove the general differences among the peers, we also added explanatory variables related to the industry into the model. Thus, we can extract the idiosyncratic return based on the company itself from stock returns, which is the residual term in the model, also called return shock and equity shock. Finally, we delayed the return shock for a year, as the instrumental variable in this paper, so that it is not related to financial characteristic variables of other peer firms.

This paper estimates the return shock by building the following model.

$$
r_{i j t}=\alpha_{i j t}+\beta_{i j t}^{M}\left(r m_{t}-r f_{t}\right)+\beta_{i j t}^{I N D}\left(\bar{r}_{-i j t}-r f_{t}\right)+\eta_{i j t}
$$

In which, $r_{i j t}$ represents the stock yield of company $\mathrm{i}$ in the industry $\mathrm{j}$ in month $\mathrm{t} .\left(r m_{t}-r f_{t}\right)$ represents the abnormal return of the market. $\left(\bar{r}_{-i j t}-r f_{t}\right)$ represents the abnormal return of weighted average stock portfolio in the industry $\mathrm{j}$ (excluding company i). $\eta_{i j t}$ represents the random disturbance term.

Expected return: $\hat{r}_{i j t}=\hat{\alpha}_{i j t}+\hat{\beta}_{i j t}^{M}\left(r m_{t}-r f_{t}\right)+\hat{\beta}_{i j t}^{I N D}\left(\bar{r}_{-i j t}-r f_{t}\right)+\eta_{i j t}$

Equity shock: $\hat{\eta}_{i j t}=r_{i j t}-\hat{r}_{i j t}$ 


\section{Empirical Analysis}

\subsection{Definition of Variables and Statistical Description of Data}

Data in this paper comes from CSMAR database of GTA. GTA's financial market data feeds and delivery platforms offer access to China's largest collection of historical data covering the most recent working day, including intraday and closing exchange pricing, fundamentals including company financial statements, corporate actions, estimates, ownership, etc. CSMAR is one of the databases under GTA. It covers all A shares and B shares companies listed on the Shanghai Stock Exchange and the Shenzhen Stock Exchange in standardized financial data presentation since the data became available in 1990.

The time span of data is from 2008 to 2015. Due to the wide use of data, we put the structure of the sample data and definition of variables in Table 1 . Table 2 shows the statistical description of the final samples in this paper. 1054 listed companies and a total of 8432 observations are included. According to the industry classification code in Guidance of Industry Classification of Listed Companies issued by China Securities Regulatory Commission in 2012, we defined different industries in the samples. Thus, 1054 listed companies in our samples are included in 55 industries. The average number of listed companies included in each industry in the samples is 19 , and the median value is 12 . The overall distribution is skewed to the right.

At the same time, Table 2 shows the statistical description of variable levels and first-order differential values. Before the empirical analysis, the variable data in this paper were winsorized on the first and the $99^{\text {th }}$ quantile. This processing helps to reduce the effects brought by extreme values and data coding errors in samples. Variables used in this paper are divided into two categories, which are firm-specific values and peer firm averages). The first kind of variables directly consist of observations of the $i^{\text {th }}$ company in the $t^{\text {th }}$ year; the structure of the second kind of variables is formed by eliminating observations of the $i^{\text {th }}$ company in the $t^{\text {th }}$ year, and then calculating the average in the industry in the year (the industry of the $i^{\text {th }}$ company).

\subsection{Results of the Construction of Equity Shock}

As stated earlier, according to the industry classification code (three-digit code) in Guidance of Industry Classification of Listed Companies issued by China Securities Regulatory Commission in 2012, we define different industries in the samples.

Table 1. Definition of variables.

\begin{tabular}{|c|c|c|c|}
\hline Category & Variable name & $\begin{array}{l}\text { Variable } \\
\text { symbol }\end{array}$ & Variable description \\
\hline \multirow{2}{*}{$\begin{array}{l}\text { Explained } \\
\text { variable }\end{array}$} & Book leverage (asset-liability ratio) & bkl & Total debt/Total assets \\
\hline & Market value leverage & mkl & Total debt/Market price of equity \\
\hline \multirow{4}{*}{$\begin{array}{l}\text { Explanatory } \\
\text { variable }\end{array}$} & Company size & size & Natural logarithm of total assets \\
\hline & Market-to-book ratio & mtbr_a & Market price of equity/Total assets \\
\hline & Profitability & prof & EBITDA/Total assets \\
\hline & Asset tangibility & tang & (Net value of fixed assets + Net value of stock)/Total assets \\
\hline \multirow{5}{*}{ Control variable } & Altman Z Scoring Value & zscore & $\begin{array}{c}1.2 * \text { current capital/total assets }+1.4 * \text { retained earnings/total assets } \\
+3.3 * \text { EBIT/total assets }+0.6 * \text { market price of equity/total } \\
\text { liabilities }+ \text { sales revenue/total assets }\end{array}$ \\
\hline & Non-debt tax shield & shield & Depreciation of fixed assets/Total assets \\
\hline & $\begin{array}{l}\text { Selling, general and administrative } \\
\text { costs }\end{array}$ & sgax & (Sales cost + management fees)/Total assets \\
\hline & Capital investment & capin & $\begin{array}{l}\text { Capital expenditure/(net value of fixed assets of the previous } \\
\text { period+ net value of inventory of the previous period) }\end{array}$ \\
\hline & $\begin{array}{l}\text { Annual rate of return of individual } \\
\text { share }\end{array}$ & stkrt & \\
\hline
\end{tabular}


Table 2. Descriptive statistics of data.

\begin{tabular}{|c|c|c|c|c|c|}
\hline & Mean & Median & Std & Max & Min \\
\hline \multicolumn{6}{|c|}{ Firm-specific } \\
\hline bkl & 0.638 & 0.540 & 2.842 & 142.7 & 0 \\
\hline $\mathrm{mkl}$ & 0.421 & 0.338 & 0.447 & 13.51 & 0 \\
\hline size & 22.12 & 22.03 & 1.539 & 29.02 & 0 \\
\hline mtbr a & 0.728 & 0.660 & 0.575 & 15.47 & 0 \\
\hline prof & 3.081 & 0.0690 & 276.5 & 25387 & -51.95 \\
\hline $\operatorname{tang}$ & 0.436 & 0.431 & 0.197 & 0.975 & 0 \\
\hline \multicolumn{6}{|c|}{ Peer Firm Average } \\
\hline pfa bkl & 0.626 & 0.552 & 1.543 & 64.86 & 0.0649 \\
\hline pfa mkl & 0.399 & 0.374 & 0.218 & 2.033 & 0.00823 \\
\hline pfa size & 22.06 & 21.96 & 0.756 & 28.92 & 18.11 \\
\hline pfa mtbr a & 0.699 & 0.672 & 0.282 & 2.862 & 0.0755 \\
\hline pfa prof & 3.083 & 0.0728 & 112.8 & 4231 & -8.576 \\
\hline pfa tang & 0.433 & 0.421 & 0.111 & 0.787 & 0.00293 \\
\hline
\end{tabular}

In this paper Rolling Window Regression was completed for the monthly stock return data of each listed company according to the return shock equation. The length of rolling window is 5 years (i.e., 60 months). The step size of each rolling is one year. At the same time, we can ensure that the observation of each rolling regression is up to 60 and at least 24 (there is at least the data of 24 months in five years). For example, to construct the stock shock of Vanke A (stock code: 000002) in 2008, we used the data of monthly return of Vanke A from January 2003 to December 2007 (five years prior to 2008) for regression according to the rolling regression equation. And then, we calculated the corresponding equity shock with the estimate coefficient obtained from the regression, (abnormal return of Vanke A on the market from January to December 2008) and (average abnormal return of peers) with reference to the calculation formula of expected return and equity shock.

Expected return: $\hat{r}_{i j t}=\hat{\alpha}_{i j t}+\hat{\beta}_{i j t}^{M}\left(r m_{t}-r f_{t}\right)+\hat{\beta}_{i j t}^{I N D}\left(\bar{r}_{-i j t}-r f_{t}\right)+\eta_{i j t}$

Equity shock: $\hat{\eta}_{i j t}=r_{i j t}-\hat{r}_{i j t}$

Table 3 shows the results of Rolling Window Regression based on Equation (2). Although the observation of samples of most rolling regression is 60 (i.e., the monthly data of 5 years), the average observation of all rolling regression samples is about 56 , and the average correction value is about $50.09 \%$.

The equity shock $\hat{\eta}_{i j t}$ calculated through the above steps is the monthly data. In order to be consistent with the accounting data period of the listed company, we used the calculation method of compound interest, and merged the equity shock of monthly data into the annual data. And then, we calculated the Peer Firm Average Equity Shock every year in every industry after company $i$ was eliminated.

In Table 4, we discussed about the partial correlation between Peer Firm Average Equity Shock and financial characteristics of company $i$. We calculated the partial correlation between the two in the same period or two adjacent periods (relative to Peer Firm Average Equity Shock), so as to prove whether Peer Firm Average Equity Shock includes current or future financial characteristic information of company $i$. In fact, the correlation between the two will not cause too many troubles for us, because the company's own financial characteristics have been added to Equation (1) as control variables.

From results in Table 4, we can see that in the model of the same period (the first column) only one estimated coefficient is significant, in which the size measuring profitability is only significant at $10 \%$ of confidence level; while in the model of two adjacent periods (the second column) all the estimated coefficients are not significant. At the same time, in the two models the numerical values of all estimated coefficient are relatively small, and 
Table 3. Results of rolling window regression.

\begin{tabular}{cccc}
\hline Variable name & Average & Median & Std \\
\hline$\hat{\alpha}_{i j t}$ & 0.175 & 0.1763 & 0.029 \\
$\hat{\beta}_{i j t}^{M}$ & 0.0002 & -0.0249 & 0.7032 \\
$\hat{\beta}_{i j t}^{I N D}$ & 0.7496 & 0.772 & 0.7051 \\
Observation per regression & 0.5009 & 0.5129 & 0.1283 \\
Adjusted R Square & 56.4992 & 58 & 4.1842 \\
$r_{i j t}$ & 0.0075 & 0.0042 & 0.1312 \\
Expected return $\hat{r}_{i j t}$ & -0.0094 & 0.0024 & 0.1193 \\
Equity shock $\hat{\eta}_{i j t}$ & 0.0131 & 0.0015 & 0.102 \\
\hline
\end{tabular}

Table 4. Character verification of Peer Firm Average Equity Shock.

\begin{tabular}{ccc} 
& \multicolumn{2}{c}{ Peer Firm Average Equity Shock } \\
& Contemporaneous & 1-Period-Lead \\
\cline { 2 - 3 } Firm-specific Factors & Independent Vars. & Independent Vars. \\
size & & 0.0119 \\
mtbr_a & $0.00849^{*}$ & $(0.0160)$ \\
& $(0.00485)$ & -0.00681 \\
prof & 0.0108 & $(0.0222)$ \\
tang & $(0.00844)$ & -0.156 \\
PFA Characteristics & -0.0440 & $(0.110)$ \\
Firm $i$ Equity Return Shock & $(0.0292)$ & 0.0773 \\
Industry Fixed Effects & 0.0246 & $(0.0626)$ \\
Year Fixed Effects & $(0.0167)$ & YES \\
Observations & YES & YES \\
R-squared & YES & YES \\
& YES & YES \\
& YES & 0.933 \\
\hline
\end{tabular}

their economic significance is not significant. The company size is the most significant explanatory variable. Its corresponding estimated coefficient is 0.00849 , which means that a unit of growth of company size will be accompanied by less than 0.01 unit of growth of Peer Firm Average Equity Shock in the same period. Therefore, we can think that the information contained by Peer Firm Average Equity Shock does not affect the financial characteristics of listed companies (in the same period or two adjacent periods).

\subsection{Results of Two-Stage Linear Regression}

We used Peer Firm Average Equity Shock as the instrumental variable of peer firm average capital structure, and used Two-stage Least Squares (2SLS) to estimate Equation (1). 
Table 5 shows estimated results of Two-stage Least Squares with Equation (1). The explained variables marked on the top of each column include book leverage, leverage of market price, first-order differential value of book leverage and first-order differential value of leverage of market price. Results of the first-stage regression are shown at the bottom of Table 5, including F statistic and $\chi^{2}$ score obtained based on DWH test of the robust standard deviation and statistics of Regression F.

Table 5. Peer Effect Recognition-Structured Estimattion (2SLS Method).

\begin{tabular}{|c|c|c|c|c|}
\hline & (1) & (2) & (3) & (4) \\
\hline VARIABLES & bkl & mkl & d_bkl & d_mkl \\
\hline \multicolumn{5}{|l|}{ Peer Firm Averages } \\
\hline \multirow[t]{2}{*}{ Dependent Variable } & 1.901 & $0.872^{* *}$ & 1.013 & $0.473^{* * *}$ \\
\hline & (3.526) & $(0.389)$ & (1.108) & $(0.168)$ \\
\hline \multirow[t]{2}{*}{ l_pfa_size } & 0.104 & -0.0515 & -0.0636 & -0.0193 \\
\hline & (0.165) & $(0.0406)$ & $(0.0624)$ & $(0.0231)$ \\
\hline \multirow[t]{2}{*}{ l_pfa_mtbr_a } & 0.0502 & $-0.0707^{*}$ & 0.0541 & 0.0382 \\
\hline & $(0.0617)$ & $(0.0390)$ & $(0.0604)$ & $(0.0672)$ \\
\hline \multirow[t]{2}{*}{ l_pfa_prof } & -0.530 & 0.158 & -0.817 & 0.0627 \\
\hline & $(0.948)$ & $(0.130)$ & $(0.961)$ & $(0.0969)$ \\
\hline \multirow[t]{2}{*}{ l_pfa_tang } & -0.579 & -0.141 & $-0.158^{*}$ & -0.103 \\
\hline & $(0.934)$ & $(0.136)$ & $(0.0894)$ & $(0.0762)$ \\
\hline \multicolumn{5}{|l|}{ Firm-specific Factors } \\
\hline \multirow[t]{2}{*}{ 1_size } & $0.0303^{* * *}$ & $0.0641^{* * *}$ & 0.00291 & $0.0338^{* * *}$ \\
\hline & $(0.00398)$ & $(0.00339)$ & $(0.00255)$ & $(0.00273)$ \\
\hline \multirow[t]{2}{*}{ l_mtbr_a } & -0.0409 & $0.146^{* * *}$ & $0.0284^{* * *}$ & $-0.264^{* * *}$ \\
\hline & $(0.0300)$ & $(0.0207)$ & $(0.0104)$ & $(0.0149)$ \\
\hline \multirow[t]{2}{*}{ l_prof } & $-0.726^{* * *}$ & $-0.633^{* * *}$ & 0.0191 & $-0.165^{* * *}$ \\
\hline & $(0.165)$ & $(0.0466)$ & $(0.0588)$ & $(0.0378)$ \\
\hline \multirow[t]{2}{*}{ 1_tang } & $0.200^{* * * *}$ & $0.158^{* * *}$ & $-0.0294^{* *}$ & 0.00561 \\
\hline & $(0.0338)$ & $(0.0164)$ & $(0.0127)$ & $(0.0138)$ \\
\hline \multirow[t]{2}{*}{ equity_shock } & -0.00371 & $-0.0448^{* * *}$ & $-0.0196^{* * *}$ & $-0.0644^{* * *}$ \\
\hline & $(0.0149)$ & $(0.00758)$ & $(0.00686)$ & $(0.00613)$ \\
\hline \multicolumn{5}{|l|}{ First Stage Statistics } \\
\hline F statistics & 0.0498 & $61.0902^{* * *}$ & 0.0029 & $90.7750^{* * *}$ \\
\hline Robust score chi2 & 0.7472 & $9.8141^{* * *}$ & 1.1266 & $3.8978^{* *}$ \\
\hline Robust Reg. F-stat & 0.7541 & $8.5747^{* * * *}$ & 1.1214 & $3.6095^{* *}$ \\
\hline Industry Fixed Effects & YES & YES & YES & YES \\
\hline Year Fixed Effects & YES & YES & YES & YES \\
\hline Observations & 8432 & 8432 & 8432 & 8432 \\
\hline Adj. R-squared & 0.450 & 0.452 & 0.400 & 0.403 \\
\hline
\end{tabular}

Notes: F statistic is the weak instrumental variable used to judge the Two-stage Least Squares Regression. The null hypothesis of the test is the existence of weak instrumental variable. Because in this paper there is only an endogenous variable, we can use F statistic. In statistical software stata we can use command estatfirststage to obtain F statistic of the first stage of regression. $\chi^{2}$ scoring and $\mathrm{F}$ statistic of regression obtained based on DWH test (Durbin-Wu-Hausman Test) of robust standard deviation are both used to judge whether the two-stage least squares regression has the endogenous explanatory variable. In this paper, they are used to judge the endophytism of $\bar{y}_{-i j}$. The null hypothesis of the test is that endogenous explanatory variable does not exist. That is to say, it is unnecessary to use two-stage least squares regression. In statistical software Stata we can use command estat endogenous to obtain robust $\chi^{2}$ scoring and F statistic of regression, respectively. 
The estimated results reported in the first row of Table 5 reports are marked as "Dependent Variable", namely the coefficient of $\bar{y}_{-i j t}$, peer average capital structure estimated through 2SLS. When the explained variables are the value of book leverage level and first-order differential value (Column (1) and (3)), the peer effect is not significant. At the same time, the first-stage statistical data in Column (2) and columns (4) shows that the instrumental variable used in this paper (Peer Firm Average Equity Shock, pfa_equity_shock) is not a weak instrumental variable, and $\bar{y}_{-i j t}$ is indeed an endogenous explanatory variable. It is necessary to use 2SLS estimation method in this paper.

Therefore, we focus on observing Column (2) and (4) in Table 5. The results show that the capital structure of its peer firms has significant and positive influence on the capital structure of listed companies (market leverage only). Specifically, 1 unit of increase of peer average market leverage will lead to the 0.872 unit of increase of the company's own market leverage. Compared with the company's own traditional financial characteristic variables, including size, prof, tang and mtbr, peer average market leverage has more significant effect with bigger numerical value. For example, in Column (2), in addition to the peer average market leverage, with the significant explanatory variable with secondary influence is profitability of the company (prof), whose estimated coefficient is -0.633 . The later one is almost $36 \%$ smaller than the former one. Similarly, mtbr, another explanatory variable with secondary influence, has the estimated coefficient of 0.641 . Its influence is also $26 \%$ smaller than the peer average market leverage.

In general, the peer effect plays an important influence role in the deciding of capital structure of listed companies. Its influence is bigger than other influencing factors of capital structure. At the same time, the peer effect existing in differences among the capital structures of listed companies is often brought by the capital structures of peer firms (Financial Action), rather than financial characteristics of peer firms.

\section{Conclusion and Enlightenment}

This paper used 1082 Chinese companies whose A shares were listed between 2008 and 2015 (including Shanghai A and Shenzhen A) as samples. Companies listed after 2003 (including 2003), financial-related industries (industry code: J66-J69), ST and PT companies, companies whose data was lost for two consecutive years, and industries conforming to the above conditions and only having one company were eliminated. The monthly data from 2003 to 2014 was used to build equity shock (including rate of return on individual share, risk-free rate of return, rate of return of comprehensive market). This paper refers to the research of Leary \& Roberts (2014) [7], and systematically discusses about the peer effect in the capital structure of listed companies in China. The empirical analysis includes building of earnings based on the company's own characteristics and equity shock; and recognition of structural formula of peer effect.

Based on the above empirical test, the conclusion of this paper is as follows. The listed company does not make the financing decision independently. On the contrary, the capital structure of listed companies is significantly influenced by their peer firms. That is to say, there is the peer effect. At the same time, the capital structures of peer firms have significant, positive, stable and healthy effect on the company's own capital structure. Its explanation ability of the capital structure of the company itself is stronger than any observed traditional capital structure influencing factor.

The above conclusion in this paper has certain enlightenment significance on the capital structure theory and capital decision-making behaviors of Chinese listed companies. It can be concluded that the peer effect of capital structure of listed companies may be related to the optimal capital structure theory. Although this paper has no rigorous proof in the theoretical analysis and empirical test, and this problem is still worth discussing about. Especially, the imitation behavior of capital structures of different companies is driven by the optimal capital structure. Solving these problems will help us to have better and deeper understanding of the influencing mechanism of peer effect.

\section{References}

[1] Graham, J.R. and Harvey, C.R. (2001) The Theory and Practive of Corporate Finance: Evidence from the Field. Journal of Financial Economics, 60, 187-243.

[2] Welch, I. (2004) Capital Structure and Stock Returns. Journal of Political Economy, 112, 106-132. http://dx.doi.org/10.1086/379933

[3] Mackay, P. and Phillips, G.M. (2005) How Does Industry Affect Firm Financial Structure? Review of Financial 
Studies, 18, 1433-1466. http://dx.doi.org/10.1093/rfs/hhi032

[4] Frank, M.Z. and Goyal, V.K. (2009) Capital Structure Decisions: Which Factors Are Reliably Important? Financial Management, 38, 1-37. http://dx.doi.org/10.1111/j.1755-053X.2009.01026.X

[5] Rajan, R.G. and Zingales, L. (1995) What Do We Know about Capital Structure? Some Evidence from International Data. The Journal of Finance, 50, 1421-1460. http://dx.doi.org/10.1111/j.1540-6261.1995.tb05184.x

[6] Marsh, P. (1982) The Choice between Equity and Debt: An Empirical Study. The Journal of Finance, 37, 121-144. http://dx.doi.org/10.1111/j.1540-6261.1982.tb01099.x

[7] Leary, M.T. and Roberts, M.R. (2010) Do Peer Firms Affect Corporate Financial Policy? Journal of Finance, 69, 139178. http://dx.doi.org/10.1111/jofi.12094

\section{Submit or recommend next manuscript to SCIRP and we will provide best service for you:}

Accepting pre-submission inquiries through Email, Facebook, Linkedin, Twitter, etc A wide selection of journals (inclusive of 9 subjects, more than 200 journals)

Providing a 24-hour high-quality service

User-friendly online submission system

Fair and swift peer-review system

Efficient typesetting and proofreading procedure

Display of the result of downloads and visits, as well as the number of cited articles

Maximum dissemination of your research work

Submit your manuscript at: http://papersubmission.scirp.org/ 